\title{
The Values of Serum and Ascetic Fluid Tumor Necrosis Factor-Alpha (TNF- alpha), TNF-Receptor 1 and C-Reactive Protein (CRP) in Patients with Cirrhotic Ascites
}

\author{
Sahar S. Zalam', Salwa M El Taher², Samia Al Taher', Aziza Khalil Omar Samy ${ }^{4}$, \\ Hasnaa S. Moustafa ${ }^{5}$, Helmy M Elshazly ${ }^{6}$, Mohamed Farag ${ }^{6}$ \\ Departments of Clinical Pathology ${ }^{1}$, Tropical Medicine ${ }^{2}$, Internal Medicine ${ }^{3}$, Physiology, \\ Biochemistry $^{5}$-Al Azhar Faculty of Medicine for Girls \& Internal Medicine ${ }^{6}$, National Liver \\ Institute-Menoufyia University
}

\begin{abstract}
Spontaneous bacterial peritonitis (SBP) is defined as an infection of initially sterile ascitic fluid (AF) without a detectable, surgically treatable source of infection. It is a frequent and severe complication of cirrhotic ascites. Because of the high morbidity and mortality of SBP, the rapid and accurate diagnosis is required. Aim: The present study aimed to measure the levels of tumor necrosis factor-alpha (TNF-alpha), tumor necrosis factor receptor (TNF-r p55) and C-reactive protein (CRP) in both ascetic fluid and serum of patients with sterile and infected cirrhotic ascites to show their diagnostic values as compared to ascitic fluid culture and polymorphnuclear leukocyte (PMN) count. Patients and methods: TNF-alpha, TNF-r p55 and CRP were measured in both ascetic fluid and serum of 20 patients with spontaneous bacterial peritonitis (SBP), in addition to 22 patients with sterile cirrhotic ascites. Results: The results of clinical examination showed a significant difference as regard abdominal pain, fever jaundice, upper GIT bleedings, encephalopathy and Sclerotherapy among both groups. The serum levels of CRP and TNF-alpha were significantly higher in patients with SBP as comparing to patients have sterile ascites, but TNF-r p55 serum level showed no significant difference. On evaluation of ascetic fluid parameters, total leucocytic count (TLC), plymorphnuclear (PMN) count, CRP, TNF-alpha, TNF-r p55 are significantly higher in SBP patient group than group of sterile ascites. Sensitivity and specificity of ascitic fluid PMN (cut-off value $>250$ cells $/ \mathrm{mm}^{3}$ ) in discriminating infected ascites from sterile ascites were $70 \%$ and $86.4 \%$, respectively. Sensitivity and specificity of ascitic fluid CRP (cut-off value $>1.0 \mathrm{mg} / \mathrm{dL}$ ) in discriminating infected ascites from sterile ascites were $85 \%$ and $72.7 \%$, respectively. Sensitivity and specificity of ascitic fluid TNF-alpha (cut off value $>12 \mathrm{pg} / \mathrm{ml}$ ) in discriminating infected ascites from sterile ascites were $80 \%$ and $63.6 \%$, respectively. Sensitivity and specificity of TNF-r p55 (cut-off value $>6.2 \mathrm{pg} / \mathrm{ml}$ ) in discriminating infected ascites from sterile ascites were $75 \%$ and $68.2 \%$, respectively. Conclusion: We concluded that, the elevated serum and ascetic fluid levels of CRP, TNF-alpha and TNF-r may suggest their role in the pathogenesis of ascetic fluid infection and their higher sensitivity and specificity make them to be good discriminators in ascetic fluid infection (especially a cheap and easy ascitic fluid CRP levels). Thus may help in rapid diagnosis and early start empirical antibiotic therapy without waiting the culture results.

\{Key wards: Ascites, spontaneous bacterial peritonitis, CRP, TNF-alpha, TNF-receptor $\}$.
\end{abstract}




\section{Introduction}

Both community and hospital acquired bacterial infections are frequently diagnosed in cirrhotics, most frequently spontaneous bacterial peritonitis (SBP), urinary tract infections, pneumonia, and skin infections. Their incidence rises with worsening liver function. Importantly, half of these episodes are asymptomatic (Borzio et al., 2001).

SBP is defined as an infection of initially sterile ascitic fluid (AF) without a detectable, surgically treatable source of infection (Garcia-Tsao, 2004). Bacterial translocation (BT), the key mechanism in the pathogenesis of SBP, is only possible because of the concurrent failure of defensive mechanisms in cirrhosis (Cirera et al., 2001). The disturbance of gut flora microecology that follows, in association with changes in the (ultra)structure of the gastrointestinal tract (Karahan et al., 2000) and reduced local and humoral immunity paves the way for the relatively free flow of microorganisms and/or endotoxins to the mesenteric lymph nodes (Ramachandran et al., 2002).

SBP is diagnosed by revealing polymorphonuclear leukocytes (PMN) in ascetic fluid $>250$ cells $/ \mathrm{mm}^{3}$. A positive cultivation finding is not necessary for diagnosing SBP, it is usually revealed in about $30 \%$ of cases (Evans et al., 2003). Some trials have mentioned a higher bacteriological detection if ascites is inoculated on the medium at the bedside as it is carried out for the investigation of blood culture - BactAlert test (Runyon 2004). In spite of the utilization of culture bottles in SBP diagnosis is now the wellestablished gold standard, it giving rise to a significant delay in result and it may be positive in about $40 \%$ of AF infection (Chinnock and Hendey, 2007).

C-reactive protein (CRP) is an acute phase $\mathrm{B}$ globulin. While the precise in vivo functions of CRP during the inflammation state is not known, there is considerable evidence indicating a role in the recognition and elimination of foreign pathogens. CRP, as an acute phase reactant, binds to different substrates. It activates the complement system, takes part in cytokine secretion and increases the phagocytosis of leukocytes (Tietz, 1995). CRP level measurements are frequently used to aid in the diagnosis of bacterial infections. CRP is synthesized by the liver, mainly in response to IL-6, which is produced not only during infection but also in many types of inflammation (Ridker, 2003).

Cytokines, also known as peptideregulating molecules, are released from the damaged tissues and induce CRP formation and secretion from hepatocytes. Tumor necrosis factor alpha (TNF- alpha) increases the synthesis of acute phase proteins from hepatocytes. TNF-alpha, is a cytokine released from the damaged tissues and induce CRP formation and secretion from hepatocytes. TNF-alpha acts via two distinct cell surface receptors, which are called TNF receptor (TNF-r) I (p55) and TNF-r II (p75) (Braegger et al., 1992). These receptors can be identified on virtually all cell types except erythrocytes. The receptor number increases proportionally in response to plasma TNFalpha levels. Besides the cell-bound forms of the TNF-r, soluble forms are known which are capable of TNF-alpha binding. Therefore, they compete with the cellbound forms and can inhibit the effects of TNF-alpha. TNF-alpha serum level may be elevated in sepsis, autoimmune diseases, various infectious diseases and transplant rejection (Yildirim et al., 2005).

There are many factors that influence the accuracy of the traditional methods used in ascetic fluid infection as false positive and negative result in addition to delayed diagnosis. Therefore, the investigators propose to use an ELISA method, standardized, rapid and automated, applicable in the context of emergency bases.

\section{Aim of the study:}

The main objective of this study was to establish the diagnostic performance (sensitivity, specificity, positive and negative predictive values) of CRP, TNFalpha and TNF-r, assayed in the serum and ascitic fluid the early diagnosis of SBP. 


\section{Patients and methods}

The present study was carried out in Hepatology Department of National Liver Institute, Menoufiya University and Departments of Tropical \& Internal Medicine of Al Zahra University hospital on 42 patients (29 males and 13 females) aged between 45-67 years. All patients included in the study present with ascites due to chronic liver disease and were diagnosed by clinical and radiological examination.

Biochemical and hematological investigations and besides microbiological culture of the ascitic fluid were routinely done to all of the patients. Complete blood count, biochemical investigations, abdominal ultrasonography and cytologic examination of the ascitic fluid were performed.

Exclusion Criteria: Ascitic patients due to other causes than chronic liver disease e.g. secondary bacterial peritonitis, tuberculous peritonitis, malignant ascites and ascites due to cardiac and renal causes, patients on antibiotic treatment at the time of study or during the preceding 10 days.

\section{The patients were divided into two groups:}

1. Liver cirrhosis with infected ascites (SBP group): Include 20 patients with SBP (14 males and 6 females), their age ranged from 48-67 years with a previous history of chronic liver disease (hepatitis C in 19 cases and hepatitis $\mathrm{B}$ in one cases). According to Child-Pugh classification, 16 of the patients were class $\mathrm{C}$ and 4 were class B. The SBP group was formed of patients either having a positive microbiological culture of the ascitic fluid or having a neutrophil count $>250 / \mathrm{mm}^{3}$ (Runyon, 1998; Yu and Hu, 2001). Ascitic fluid culture positivity was detected in 5 patients (E. coli in 4, Staph. aureus in one case). In 4 patients with a fever $>38^{\circ} \mathrm{C}$, the same organism was detected also in the blood (E. coli in 2, Staph. aureus in one case).
2. Liver cirrhosis with sterile ascites: Includes 22 patients $(15$ males and 7 females), their age ranged from 45-64 years. Hepatitis $\mathrm{C}$ was positive in 20 and hepatitis B was positive in 2 patients. According to Child-Pugh classification, 18 patients were class $\mathrm{C}$, and 4 patients were class B.

\section{All patients included in the study were subjected to the following:}

1- History of episodes of GI bleeding suggesting portal hypertension, invasive procedures: GI endoscopy and paracentesis, episodes of fever and abdominal pain, drug history including antibiotics, history of viral hepatitis infection.

2- Clinical examination: with special stress on presence or absence of fever, jaundice, ascites, spleen enlargement, liver enlargement, the presence of abdominal tenderness.

3- Abdominal ultrasound: Liver, spleen, presence of focal legions, and ascites were examined.

4- Ascitic fluid examination: Paracentesis was done under complete aseptic conditions, the patient lies in his bed in semi setting position, we used large boar canula and we putted it med way between umbilicus and anterior superior iliac spine. The ascitic fluid was injected into the bedside blood culture bottles. Also another ascitic fluid sample was sent to the laboratory in two separate sterile tubes. One tube of ascitic fluid was centrifuged. The supernatants were stored in $-70^{\circ} \mathrm{C}$ until measurements of CRP, TNF-alpha and TNF-r.

The other tube examined for color, aspect and odor, TLC on automatic cell counter Sysmex KX-21. and differential PMN count by Leishman stain. LDH, glucose, total protein and albumin levels in ascitic fluid and serum were measured using Hitachi 911 (Roche-Germany). Microbiological cultures of ascitic fluid and blood were done by inoculating $10 \mathrm{ml}$ of ascitic fluid at the bedside in two blood culture bottles, one for aerobic and the other for anaerobic tests under complete aseptic condition and incubation: at $37^{\circ} \mathrm{C}$ 
for 10 days with continuous shaking of bottles. The growth is detected through blind subcultures or turbidity of the media. Subcultures were done on blood agar and MacConkey's agar plates (Forbes et al., 1998). Identification of the growing colonies occurred by Gram's staining for the growing colonies. Organisms were identified through API 20E and API strip. API $20 \mathrm{E}$ is an identification system for Enterobacteriaceae and other gram-negative rods, while API strip is used for identification of streptococci. The API identification system is a strip consisting of microtubes containing dehydrated substrates. These tests are inoculated with a bacterial suspension that reconstitutes the media. During incubation, metabolism produces color changes that are either spontaneous or revealed by the addition of reagents. The reactions are read according to the reading table and the identification is obtained by referring to the analytical profile index. Antibiotic susceptibility test: done by disk-diffusion method on MullerHinton agar. All patients were given empirical antibiotics which started immediately after taking samples for cultures and this empirical antibiotic regimen was modulated according to the results of culture and antibiotic sensitivity tests.

4- C-reactive protein (CRP) was assessed quantitatively in serum and ascetic fluid using Axyem (Roche- Germany).

5- TNF- alpha and TNF-r p55 levels were assayed by ELISA method using Quantikine kit for the quantitative determination of human tumor necrosis factor alpha (TNF-alpha) or TNF- receptor p55 (TNF-r p55) in human serum and plasma (R \& D- UK). This assay employs the quantitative sandwich enzyme immunoassay technique. A monoclonal antibody specific for TNF-alpha or TNF-r p55 has been pre-coated onto a microplate. Standards and samples are pipette into the wells and any TNF-alpha or TNF-r p55 present is bound by the immobilized antibody. After washing away any unbound substances, an enzyme-linked polyclonal antibody specific for TNF-alpha or TNF-r p55 is added to the wells. Following a wash to remove any unbound antibody-enzyme reagent, a substrate solution is added to the wells. After an incubation period, an amplifier solution is added to the wells and color develops in proportion to the amount of TNF-alpha or TNF-r p55 bound in the initial step. The color development is stopped and the intensity of the colour is measured (Engelmann et al., 1990).

\section{Statistical analysis}

The SPSS computer program version 12.0 was used for statistical analysis. Data are expressed as mean $\pm \mathrm{SD}$. Student's t-test for parametric data and Mann-Whitney $\mathrm{U}$ for non parametric data were done. Chisquare test $\left(\mathrm{X}^{2}\right)$ for qualitative data. All tests were two-tailed and $\mathrm{p}$-values $<0.05$ were considered significant. Sensitivity and specificity of ascetic fluid CRP, TNF-alpha and TNF-r were also calculated. Sensitivity was calculated as: true positive/(true positive + false negative) $\times 100$; specificity as: true negative/(true negative + false positive) x 100 .

\section{Results}

The results of clinical examination is summarized in table (1), which showed a significant difference as regard abdominal pain, fever jaundice, upper GIT bleedings, encephalopathy and Sclerotherapy. However there were no significant differences as regard presence of lower limb edema, and history of paracentesis among both groups.

Biochemical examinations of the blood and ascetic fluid of the patients are summarized in Tables $(\mathbf{2} \& \mathbf{3})$. Serum levels of CRP and TNF-alpha were significantly higher in patients with SBP as comparing to patients have sterile ascites $(\mathrm{p}<0.01,<0.01)$ respectively. In contrast, no significant differences were detected as regard liver function and kidney tests, TLC, platelet counts, serum/ascites albumin gradient ratio or serum levels of TNF-r p55 among both patient groups (Table 2).

On evaluation of ascetic fluid parameters, TLC, PMN, CRP, TNF-alpha, 
TNF-r p55 are significantly higher in SBP patient group than group of sterile ascites, There was no statistically significant difference in the rest of the parameters (Tables 3 \& Figure 1 ).

To give a value for the results, the sensitivity and specificity of PMN cells, CRP, TNF-alpha and TNF-r were calculated at different cut-off. The sensitivity and specificity of ascetic fluid PMN (cut-off value $>250$ cells $/ \mathrm{mm}^{3}$ ) in discriminating infected ascites from sterile ascites were $70 \%$ and $86.4 \%$, respectively.
Sensitivity and specificity of ascetic fluid CRP (cut-off value $>1.0 \mathrm{mg} / \mathrm{dL}$ ) in discriminating infected ascites from sterile ascites were $85 \%$ and $72.7 \%$, respectively. Sensitivity and specificity of ascetic fluid TNF-alpha (cut-off value $>12 \mathrm{pg} / \mathrm{ml}$ ) in discriminating infected ascites from sterile ascites were $80 \%$ and $63.6 \%$, respectively. Sensitivity and specificity of TNF-r p55 (cut-off value $>6.2 \mathrm{pg} / \mathrm{ml}$ ) in discriminating infected ascites from sterile ascites were $75 \%$ and $68.2 \%$, respectively (Table 4).

Table (1): Comparison between clinical findings of two studied groups.

\begin{tabular}{|c|c|c|c|c|c|}
\hline \multirow{2}{*}{ Clinical data } & \multicolumn{2}{|c|}{ SBP group $(N=20)$} & \multicolumn{2}{|c|}{$\begin{array}{l}\text { Sterile ascites group } \\
(\mathrm{N}=22)\end{array}$} & \multirow{2}{*}{ P-value } \\
\hline & No. & $\%$ & No. & $\%$ & \\
\hline Abdominal pain & 12 & $60 \%$ & 6 & $27.3 \%$ & $<0.05^{*}$ \\
\hline Fever & 15 & $75 \%$ & 8 & $36.8 \%$ & $<0.05^{*}$ \\
\hline Jaundice & 8 & $40 \%$ & 5 & $22.7 \%$ & $<0.05^{*}$ \\
\hline Upper GIT bleeding & 11 & $55 \%$ & 4 & $18.2 \%$ & $<0.05^{*}$ \\
\hline Lower limb edema & 6 & $30 \%$ & 7 & $31.8 \%$ & $>0.05$ \\
\hline Encephalopathy & 10 & $50 \%$ & 3 & $13.6 \%$ & $<0.05^{*}$ \\
\hline Sclerotherapy & 12 & $60 \%$ & 5 & $22.7 \%$ & $<0.05^{*}$ \\
\hline Paracentesis & 9 & $45 \%$ & 9 & $40.9 \%$ & $>0.05$ \\
\hline
\end{tabular}

$* \mathrm{P}<0.05$ is significant, $\mathrm{p}>0.05$ is non significant.

Table (2): Comparison between laboratory tests of two studied groups.

\begin{tabular}{|c|c|c|c|}
\hline \multirow[t]{2}{*}{ Laboratory tests } & $\begin{array}{c}\text { SBP group } \\
(\mathrm{N}=\mathbf{2 0})\end{array}$ & $\begin{array}{l}\text { Sterile ascites } \\
\text { group }(\mathrm{N}=\mathbf{2 2})\end{array}$ & \multirow[t]{2}{*}{$P$ value } \\
\hline & $\mathrm{M} \pm \mathrm{SD}$ & $\mathrm{M} \pm \mathrm{SD}$ & \\
\hline $\operatorname{ALT}(\mathrm{U} / \mathrm{L})$ & $63.2 \pm 10.7$ & $67.4 \pm 11.3$ & $>0.05$ \\
\hline $\operatorname{AST}(\mathrm{U} / \mathrm{L})$ & $65.4 \pm 12.8$ & $52.5 \pm 8.3$ & $>0.05$ \\
\hline Total bilirubin (mg/dl) & $4.9 \pm 1.3$ & $4.2 \pm 1.1$ & $>0.05$ \\
\hline Serum albumin $(\mathrm{gm} / \mathrm{dl})$ & $2.3 \pm 0.4$ & $2.5 \pm 0.12$ & $>0.05$ \\
\hline Serum/ascites albumin gradient & $1.72 \pm 0.32$ & $1.91 \pm 0.078$ & $>0.05$ \\
\hline Prothrombin conc $(\%)$ & $59.8 \pm 12.4$ & $53.3 \pm 9.2$ & $>0.05$ \\
\hline Blood urea (mg/dl) & $64.3 \pm 15.4$ & $70.1 \pm 18.4$ & $>0.05$ \\
\hline Serum creatinine $(\mathrm{mg} / \mathrm{dl})$ & $1.8 \pm 0.4$ & $1.6 \pm 0.3$ & $>0.05$ \\
\hline WBCs $\left(\times 10^{3} / \mathrm{mm}^{3}\right)$ & $12.6 \pm 3.6$ & $9.4 \pm 2.1$ & $>0.05$ \\
\hline Platelets $\left(\mathrm{x} 10^{3} / \mathrm{mm}^{3}\right)$ & $129 \pm 38$ & $121 \pm 30$ & $>0.05$ \\
\hline CRP (mg/dl) & $5.0 \pm 1.13$ & $1.62 \pm 0.7$ & $<0.01 * *$ \\
\hline TNF-alpha (pg/mL) & $26.8 \pm 3.14$ & $13.9 \pm 3.61$ & $<0.01 * *$ \\
\hline TNF-r p55 (pg/mL) & $21.4 \pm 5.36$ & $17.6 \pm 2.02$ & $>0.05$ \\
\hline
\end{tabular}

$* \mathrm{P}<0.05$ is significant, ${ }^{* *} \mathrm{p}<0.01$ is highly significant, $\mathrm{p}>0.05$ is non significant. 
Table (3): Comparison between biochemical ascitic fluid examination of the studied groups.

\begin{tabular}{|l|l|l|l||}
\hline \multicolumn{1}{|c|}{ AF examination } & \multicolumn{1}{|c|}{$\begin{array}{c}\text { SBP group } \\
\text { (N=20) }\end{array}$} & $\begin{array}{c}\text { Sterile ascites } \\
\text { group (N=22) }\end{array}$ & \multirow{2}{*}{ P value } \\
\cline { 2 - 3 } & \multicolumn{1}{|c|}{$\mathrm{M} \pm \mathrm{SD}$} & \multicolumn{1}{|c|}{$\mathrm{M} \pm \mathrm{SD}$} & \\
\hline AF total protein $(\mathrm{gm} / \mathrm{dl})$ & $1.7 \pm 0.41$ & $1.4 \pm 0.21$ & $>0.05$ \\
\hline AF albumin $(\mathrm{gm} / \mathrm{dl})$ & $0.71 \pm 0.13$ & $0.56 \pm 0.16$ & $>0.05$ \\
\hline AF glucose $(\mathrm{mg} / \mathrm{dl})$ & $134 \pm 28$ & $119 \pm 20$ & $>0.05$ \\
\hline AF LDH $(\mathrm{U} / \mathrm{L})$ & $142 \pm 31$ & $161 \pm 47$ & $>0.05$ \\
\hline AF TLC / mm ${ }^{3}$ & $1129 \pm 250$ & $285 \pm 62$ & $<0.05^{*}$ \\
\hline AF PMN $\left(\mathrm{cells} / \mathrm{mm}^{3}\right)$ & $985 \pm 302$ & $133 \pm 42$ & $<0.05^{*}$ \\
\hline AF CRP $(\mathrm{mg} / \mathrm{dL})$ & $3.65 \pm 1.21$ & $1.95 \pm 0.87$ & $<0.05^{*}$ \\
\hline AF TNF-alpha $(\mathrm{pg} / \mathrm{mL})$ & $40.66 \pm 8.45$ & $16.52 \pm 7.13$ & $<0.001^{* *}$ \\
\hline AF TNF-r p55 $(\mathrm{pg} / \mathrm{mL})$ & $26.13 \pm 4.15$ & $11.24 \pm 2.96$ & $<0.01^{* *}$ \\
\hline
\end{tabular}

$* \mathrm{P}<0.05$ is significant, $* * \mathrm{p}<0.01$ is highly significant, $\mathrm{p}>0.05$ is non significant.

Table (4): The sensitivity and specificity of some AF parameters in SBP diagnosis

\begin{tabular}{|l|l|l|l|l|}
\hline \multicolumn{1}{|c|}{ AF parameters } & Sensitivity & Specificity & PPV & NPV \\
\hline \hline AF PMN (cells / mm $\left.{ }^{3}\right)$ & $70 \%$ & $86.4 \%$ & $77.8 \%$ & $75 \%$ \\
\hline AF CRP (mg/dL) & $85 \%$ & $72.7 \%$ & $73.9 \%$ & $84.2 \%$ \\
\hline AF TNF-alpha (pg/mL) & $80 \%$ & $63.6 \%$ & $66.7 \%$ & $77.8 \%$ \\
\hline AF TNF-r p55 (pg/mL) & $75 \%$ & $68.2 \%$ & $68.1 \%$ & $75 \%$ \\
\hline
\end{tabular}

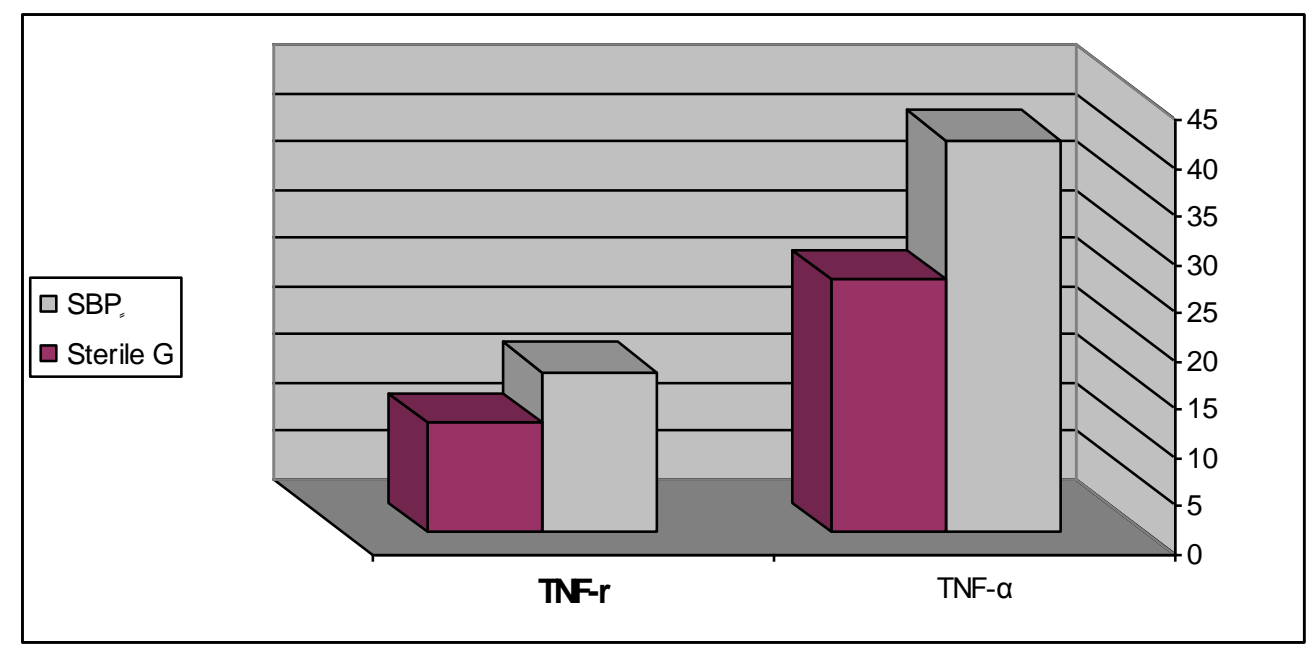

Figure (1): The ascetic fluid levels of TNF-alpha and TNF-r p55 in SBP and sterile ascites patient groups. 


\section{Discussion}

SBP is a major problem encountered in patients with liver cirrhosis, with an incidence of $5-30 \%$ of all infections, and hospital mortality constitutes about $50 \%$ of all SBP cases (Mackiewics et al., 1991). Obviously, a positive bacteriological culture of ascetic fluid is the "gold standard" and prerequisite for the diagnosis of SBP. The value of ascetic leukocyte count has been studied in detail and is still accepted as a "silver standard" diagnostic criterion for SBP (Yildirim et al., 2005).

The combination of an elevated PMN count and the yield of cultures of the ascitic fluid are considered the gold standard for the diagnosis of SBP, but, it has some shortcomings. First, the results of ascitic fluid culture are not readily available, postponing the diagnosis and treatment of the infection (Rimola et al., 2000). Second, one of the most frequent variants of ascitic fluid infection is culture-negative neutrocytic ascites, which occurs in approximately $30 \%$ to $50 \%$ of patients (Moore et al., 2003; Runyon, 2004). Thus, the investigators propose to use an ELISA method, standardized, rapid and automated, applicable in the context of emergency bases.

The clinical examination in our study revealed that, abdominal pain, fever jaundice, upper GIT bleedings, encephalopathy and Sclerotherapy were more frequent with cases of SBP. This could be expected since previous reports stated that abdominal pain and fever are the most characteristic symptoms in patients with spontaneous ascetic fluid infection (Chang et al., 1998 \& Amin et al., 2002).

In this study, ascetic fluid culture was positive in only 5 cases $(25 \%)$ out of 20 SBP patients (E. coli in 4, Staph. aureus in one case). This low frequency may be explained by, the process of bacterial opsonization that takes place in blood or ascetic fluid makes the bacteria non viable in routine cultures (Such $\boldsymbol{e t}$ al., 2002). This predominance of Gram-negative infection is consistent with the results of Toledo $\boldsymbol{e t}$ al. (1994) and Nooman et al. (1999).
Similar results observed by Rimola $\boldsymbol{e t}$ al. (2000) who stated that Gram negative bacilli of the Enterobacteriaceae family, particularly E. coli, are the most common organisms causing SBP, accounting for more than $60 \%$ of cases. This can be explained by the fact that the organisms predominantly causing ascetic fluid infection are normally found in the gastrointestinal tract (수untu and Benea, 2006).

Also, no anaerobic organisms were detected in ascitic fluid culture in our study group and this is consistent with the results of Amin et al. (2002). This infrequency of anaerobic spontaneous ascitic fluid infection is probably due to the inability of anaerobes to translocate across the mucosa and the relatively high $\mathrm{PO}_{2}$ of ascetic fluid. The concentration of CRP in serum has been found to be helpful in the diagnosis and management of patients with a wide variety of inflammatory conditions. An abnormal serum CRP level was found in $72 \%$ of cirrhotic patients complicated with bacterial infections, gastrointestinal bleeding, hepatic encephalopathy or massive ascites (Lee $\boldsymbol{e t}$ al., 1990).

In the current study, the serum CRP concentration was found to differentiate patients with infected ascetic fluid (SBP group) from patients have sterile ascites better than the ascetic fluid CRP concentrations. However, the serum CRP values were significantly higher in patients with SBP than in patients with sterile ascites. In Yildirim et al. (2005) study, mean ascitic fluid CRP levels were detected to be higher in the SBP and malignant groups than the sterile cirrhotic ascites group. They added that, serum CRP levels were higher in the SBP group than the malignant and sterile cirrhotic ascites group.

In contrast Runyon (1998) reported the ascetic fluid CRP concentrations of patients with sterile portal-hypertension-related ascites were not significantly different from those of infected specimens. The reason for these unexpected results is that the CRP is not produced in the inflamed body cavity but is produced in the liver and only enters 
a body cavity by leakage of serum protein into the body fluid.

The previous studies stated that, high plasma levels of TNF-alpha were found in patients with infectious diseases and in patients with fulminant hepatic failure and alcoholic hepatitis (Zeni et al., 1993). Our study revealed that, TNF-alpha serum and ascetic fluid levels were significantly increased in patients with SBP as comparing to patients have sterile ascites. This finding was in agreement with, Yildirim et al. (2005) who detected elevated levels of ascetic fluid TNF-alpha in the SBP group when compared with uncomplicated sterile cirrhotic ascites group. Also, serum TNF-alpha was detected to be higher in SBP when compared with the sterile cirrhotic ascites group.

The liver is an important site of synthesis and the major organ for clearance of several cytokines. The source of cytokines found in the ascetic fluid of the patients is unknown. Cytokines in ascitic fluid in SBP probably derive from the peritoneal macrophages and mesothelial cells (Topley et al., 1993). High mean ascetic fluid-to-plasma ratios of TNF-alpha levels could suggest that the elevated TNFalpha concentration may reflect not only increased peritoneal permeability but also increased local synthesis of the cytokines (Zeni et al., 1993 \& Tietz, 1995).

Topley et al. (1993), reported that, the decreased levels of TNF-alpha in ascitic fluid during the first 48 hours of antibiotic treatment in SBP patients suggest that the inflammatory response to infection, as estimated by the levels of cytokines in plasma or ascetic fluid, is increased in cirrhotic patients and that cytokines may have prognostic significance in patients with liver failure

The present study, reported a significant increase of ascetic fluid TNF-r p55 level in SBP patient group compared to sterile ascites patients, however, its serum level was increased but not reached statistical difference. This finding was similar to Lata et al. (2009) results. On the contrary, (Zeni et al., 1993) recorded that, patients with infected ascites showed higher soluble TNF-r concentrations in plasma than in patients with sterile hepatic ascites. Lantz et al. (1990) reported that, bacterial products may induce TNF-alpha and soluble TNF-r elevation from the leukocytes in the infected ascites. The elevated TNF-alpha levels in the circulation cause un increase in TNF-r levels. The discrepancy between their results and ours may explained by our small sample size of the patients and most of our patients were diagnosed for SBP early to start empirical antibiotic therapy.

To give a value for the results, the sensitivity and specificity of PMN cells, CRP, TNF-alpha and TNF-r p55 were calculated at different cut-off. Sensitivity and specificity of ascetic fluid PMN (cutoff value $>250$ cells $/ \mathrm{mm}^{3}$ ) in discriminating infected ascites from sterile ascites were $70 \%$ and $86.4 \%$, respectively. Sensitivity and specificity of ascetic fluid CRP (cut-off value $>1.0 \mathrm{mg} / \mathrm{dL}$ ) in discriminating infected ascites from sterile ascites were $85 \%$ and $72.7 \%$, respectively. Sensitivity and specificity of ascetic fluid TNF-alpha (cut-off value $>12 \mathrm{pg} / \mathrm{ml}$ ) in discriminating infected ascites from sterile ascites were $80 \%$ and $63.6 \%$, respectively. Sensitivity and specificity of ascetic fluid TNF-r p55 (cut-off value $>6.2 \mathrm{pg} / \mathrm{ml}$ ) in discriminating infected ascites from sterile ascites were $75 \%$ and $68.2 \%$, respectively.

In Yildirim et al. (2005) study, sensitivity and specificity of ascites fluid CRP in discriminating SBP from sterile ascites were $90 \%$ and $76 \%$, respectively. CRP levels may be elevated in the ascitic fluid due to increased capillary permeability in SBP group. Moreover, the clearance of CRP in the ascetic fluid was unknown. CRP may also accumulate in the local inflammatory events as well (Corrall $\boldsymbol{e t}$ al.,1981).

Also, Yildirim et al., (2005) study reported the sensitivity and specificity of ascetic fluid TNF-alpha in discriminating infected ascites from sterile ascites were $82 \%$ and $66 \%$, respectively. In addition, sensitivity and specificity of TNF-r in discriminating infected ascites from sterile ascites were $80 \%$ and $76 \%$, respectively. In another study by Andus et al. (1992), the sensitivity and specificity of TNF-r p55 in 
infected ascites from uncomplicated ascites of chronic liver disease were $86 \%$ and $95 \%$.

\section{Conclusion:}

From the above results we conclude that, the elevated serum and ascetic fluid levels of CRP, TNF-alpha and TNF-r may suggest their role in the pathogenesis of ascetic fluid infection. Moreover, their higher sensitivity and specificity of ascetic fluid levels make them to be good discriminators in ascetic fluid infection (especially a cheap and easy ascetic fluid CRP levels). Thus may help in rapid diagnosis and early start empirical antibiotic therapy without waiting the culture results.

\section{References}

Amin M, Bebars A and El Gindy I (2002): Comparative study of ascetic fluid Bactec culture with other microbiological culture techniques and fibronectin assay value for rapid diagnois of spontaneous bacterial peritonitis. Egypt J. Med. Lab. Sci., 11(2):9.

Andus T, Gross V, Holstege A, et al. (1992): High concentrations of soluble tumor necrosis factor receptors in ascites. Hepatology., 16:749755.

Aruntu FA and Benea L. (2006): Spontaneous bacterial peritonitis: pathogenesis, diagnosis, treatment. J Gastrointestin Liver Dis., 15: 51-56.

Borzio M, Salerno F, Piantoni $L$, et al. (2001): Bacterial infection in patients with advanced cirrhosis: a multicentre prospective study. Dig Liver Dis., :33:41-48.

Braegger CP, Nicholls S, Murch SH, et al. (1992): Tumour necrosis factor alpha in stool as a marker of intestinal inflammation. Lancet, 39:89-91.

Chang CS, Chen GH and Lien HC (1998): Small intestine dysmotility and bacterial overgrowth in cirrhotic patients with spontaneous bacterial peritonitis. Hepatology, 28: 1187.

Chinnock B and Hendey GW. (2007): Can clear ascitic fluid appearance rule out spontaneous bacterial peritonitis? Am J Emerg Med., 25: 934-937.

Cirera I, Bauer TM, Navasa M, Rodés J. et al. (2001): Bacterial translocation of enteric organisms in patients with cirrhosis. $J$ Hepatol., 34: $32-37$
Corrall CJ, People JM, Moxon ER, et al. (1981): C-reactive protein in spinal fluid of children with meningitis. J Pediatr., 99:365-369. Engelmann H, Liabakk NB, Sundan A, Waage A, Espevik $T$ et al. (1990): Development of immunoassays for the detection of soluble tumour necrosis factor receptors. J. Biol. Chem. 265:1531.

Evans LT, Kim WR, Poterucha JJ and Kamath PS. (2003): Spontaneous bacterial peritonitis in asymptomatic outpatients with cirrhotic ascites. Hepatology, 37: 897-901.

Forbes BA, Sahn DF and Weissfeld AS (1998): Diagnosis by organ system. In: Forbes BA, Sahn DF and Weissfeld AS. Bailey; PP 456.

Garcia-Tsao G. (2004): Spontaneous bacterial peritonitis: a historical perspective. J Hepatol., 41: 522-527.

Karahan OI, Dodd GD, Chintapalli KN, Rhim $H$ and Chopra S. (2000): Gastrointestinal wall thickening in patients with cirrhosis: frequency and patterns at contrastenhanced CT. Radiology, 215: 103-107.

Lantz M, Gullberg V, Nilsson E, et al. (1990): Characterization in vitro of human TNF-binding protein: a soluble form of TNF receptor. J Clin Invest., 86:1396-1402.

Lata J, Stiburek O and Kopacova M. (2009): Spontaneous bacterial peritonitis: A severe complication of liver cirrhosis. World $J$ Gastroenterol., 28; 15(44): 5505-5510.

Lee FY, Lee SD, Tsai YT, et al. (1990): Serum C-reactive protein as a serum marker for the diagnosis of hepatocellular carcinoma. Cancer. ,63:1567-1571.

Mackiewics A, Speroff T, Ganapathi MK, et al. (1991): Effects of cytokine combinations on acute phase protein production in two human hepatoma cell lines. J Immunol., 146:30323037.

Moore K.P., Wong F., Gines P, et al.(2003): The management of ascites in cirrhosis: report on the consensus conference of internacional ascites club. Hepatology., 38:258-266.

Nooman Z, Serwah A, Abo El-Ela A and Attia F (1999): Determination of the prevalence and risk factors of spontaneous bacterial peritonitis in patients with ascites due to chronic liver disease. Egypt. J. Lab. Med.., 11(2): 451455.

Ramachandran A, Prabhu R, Thomas S et al. (2002): Intestinal mucosal alterations in experimental cirrhosis in the rat: role of oxygen free radicals. Hepatology., 35: 622-629.

Ridker PM. (2003): Clinical application of Creactive protein for cardiovascular disease 
detection and prevention. Circulation., 107:363369.

Rimola A, Garcia-Tsao G, Navasa M, et al (2000): Diagnosis, treatment and prophylaxis of spontaneous bacterial peritonitis: a consensus document. Journal of Hepatology, 32: 142-147.

Runyon BA (1998): Ascites and spontaneous bacterial peritonitis. In: Feldman M, Scharschmidt BF and Sleisenger MH. Gastrointestinal and liver disease pathology diagnosis/ management. Philadelphia: PP 1314.

Runyon B.A. (2004): Early events in spontaneous bacterial peritonitis. Gut, 63:782784.

Such J, Frances R, Munoz C et al. (2002): Detection and identification of bacterial DNA in patients with cirrhosis and culture-negative nonneutrocytic ascites. Hepatology, 36: 135-139.

Tietz NW, ed. (1995): Clinical guide to laboratory tests. $3^{\text {rd }}$ ed. Philadelphia: WB Saunders., PP 358.
Toledo ME, Pereyra LH and Suzuki S (1994): Cellular and bio-molecular mechanisms of liver ischemia. Transport PROC, 26: 326.

Topley N, Jorres A, Luttmann W, et al. (1993): Human peritoneal mesothelial cells synthesize IL-6: Induction by IL-1 alpha and TNF-alpha. Kidney Int., 43:226-233.

Yildirim B, Sari R, and Isci $N$ and Turkey $M$ (2005): Patients with Spontaneous Bacterial Peritonitis, and Malignant and Cirrhotic Ascites. J Nat Med Assoc., 97, (2):201-206.

Yu AS and Hu K (2001): Management of ascites. Clinics in liver disease, 5 (2):1-6.

Zeni F, Tardy B, Vindimian M, et al. (1993): High levels of tumor necrosis factor-a and interleukin-6 in the ascitic fluid of cirrhotic patients with spontaneous bacterial peritonitis. Clin Infect Dis.,17:218223. 


\section{قيمة قياس نسبة عامل تحلل خلايا الأورام ألفا ونسبة مستقبلات تعلل خلايا الأورام

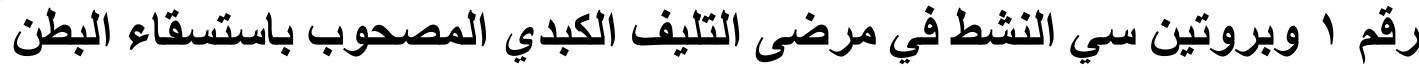

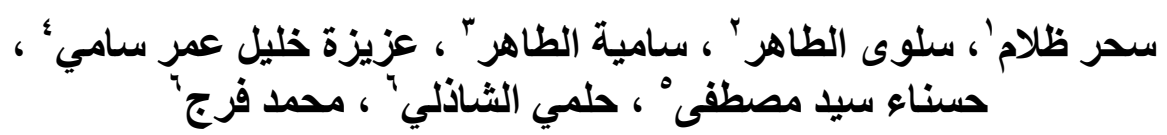

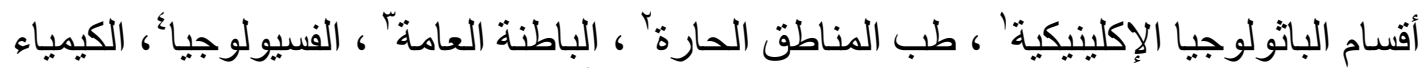

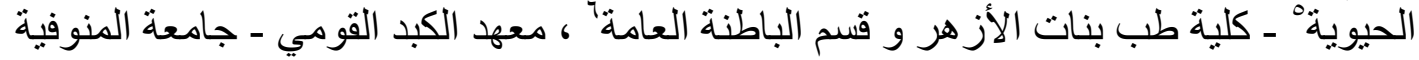

المقدمة: التهاب الغشاء البروتونى البكتيرى التلقائى يعرف بانه التهاب فى سائل استسقاء البطن

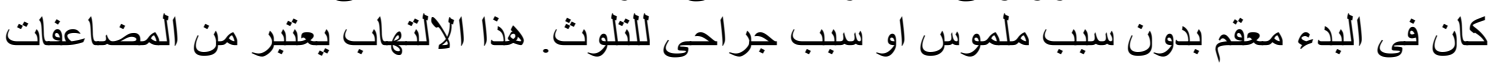

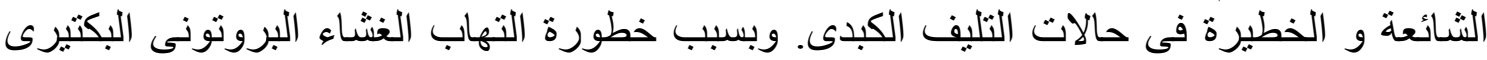

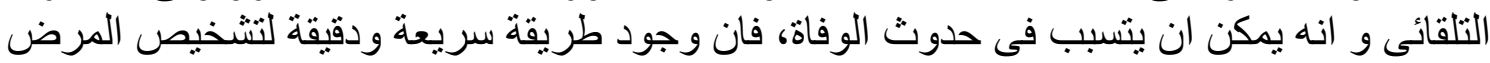
امر مرغوب فيه بشدة.

الهاف من البحث: ان الهذف الرئيسى من البحث هو دراسة مدى حساسية كلا من عامل تحلل

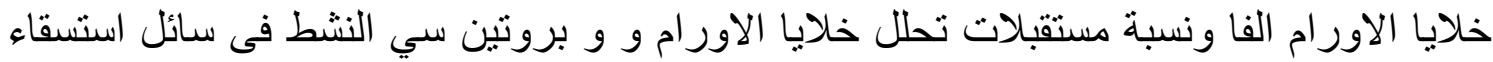

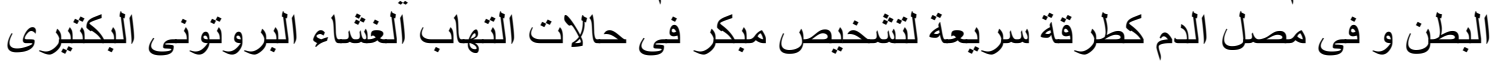

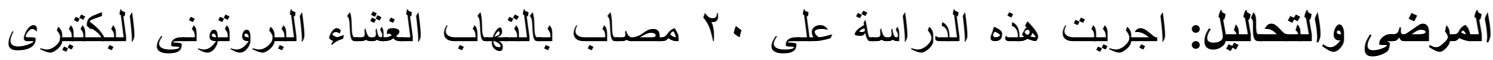

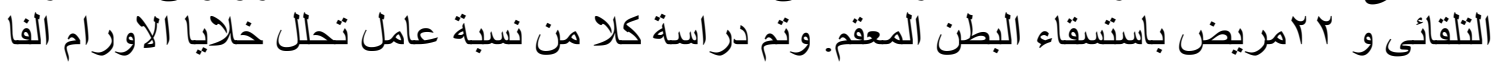

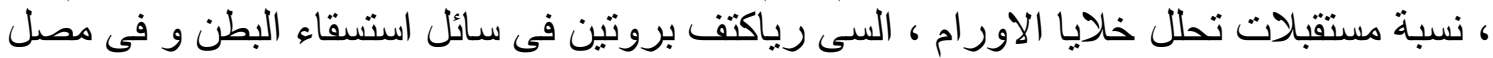

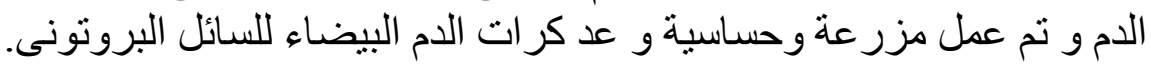

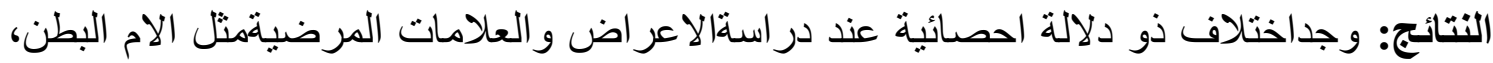

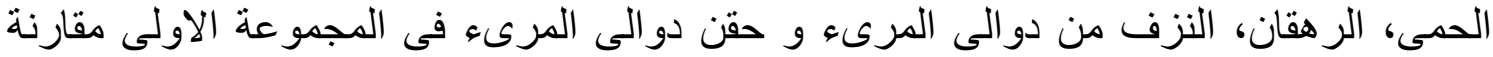

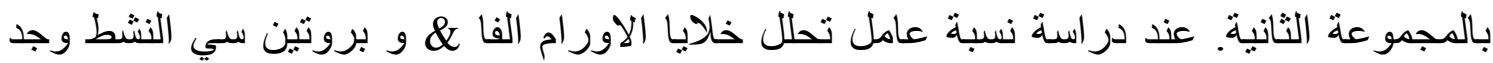

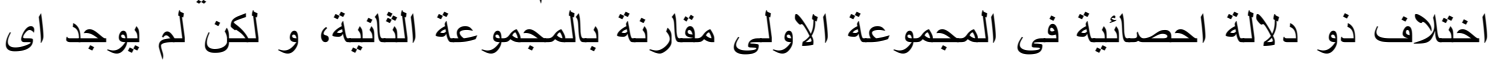

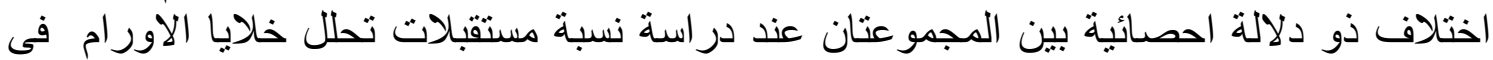

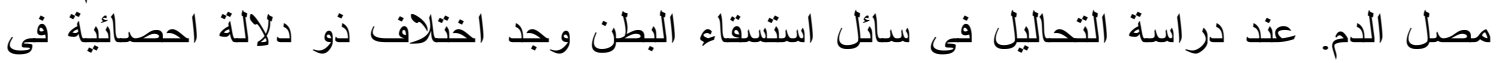

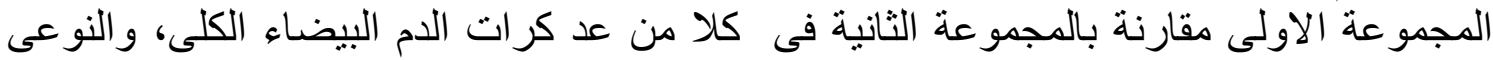

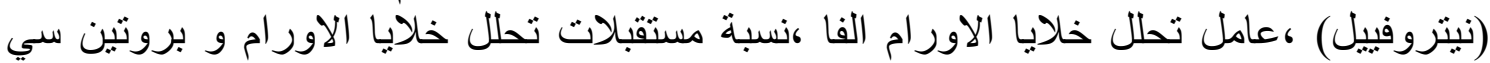

الخلاصة: استخلاصنا من هذه الدراسة ان ارتفاع نسبة كلا من عامل تحلل خلايا الاور ام الفا ونسبة التابة

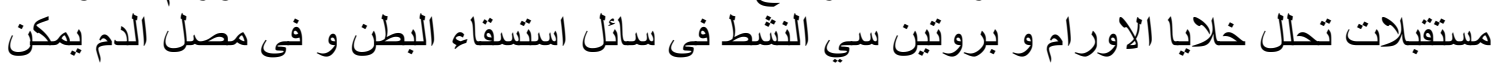

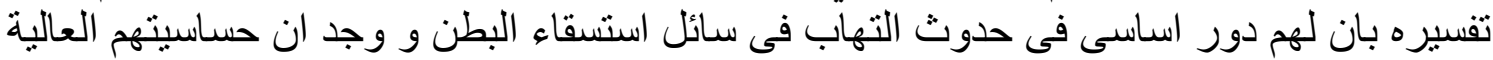

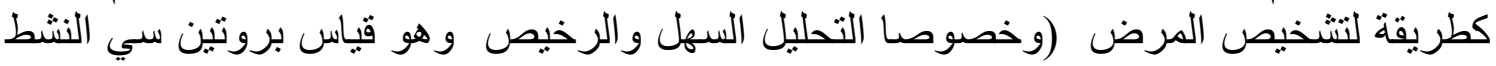

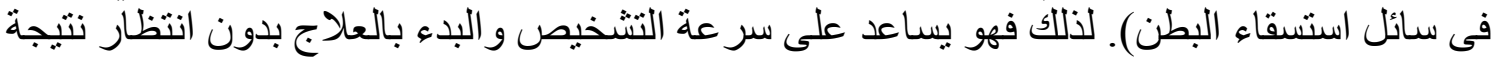
مزر عة وحساسية للسائل البروتونى. لألى فئل 